\title{
Intravenous ascorbic acid to prevent and treat cancer-associated sepsis?
}

\author{
Thomas E Ichim 1,2, Boris Minev ${ }^{3}$, Todd Braciak ${ }^{2,4}$, Brandon Luna², Ron Hunninghake', Nina A Mikirova ${ }^{1}$, \\ James A Jackson ${ }^{1}$, Michael J Gonzalez ${ }^{5}$, Jorge R Miranda-Massari ${ }^{6}$, Doru T Alexandrescu ${ }^{7}$, Constantin A Dasanu ${ }^{8}$, \\ Vladimir Bogin ${ }^{2}$, Janis Ancans ${ }^{9}$, R Brian Stevens ${ }^{10}$, Boris Markosian ${ }^{2}$, James Koropatnick ${ }^{11}$, Chien-Shing Chen ${ }^{12}$, \\ Neil H Riordan ${ }^{1,2^{*}}$
}

\begin{abstract}
The history of ascorbic acid (AA) and cancer has been marked with controversy. Clinical studies evaluating AA in cancer outcome continue to the present day. However, the wealth of data suggesting that AA may be highly beneficial in addressing cancer-associated inflammation, particularly progression to systemic inflammatory response syndrome (SIRS) and multi organ failure (MOF), has been largely overlooked. Patients with advanced cancer are generally deficient in AA. Once these patients develop septic symptoms, a further decrease in ascorbic acid levels occurs. Given the known role of ascorbate in: a) maintaining endothelial and suppression of inflammatory markers; b) protection from sepsis in animal models; and c) direct antineoplastic effects, we propose the use of ascorbate as an adjuvant to existing modalities in the treatment and prevention of cancer-associated sepsis.
\end{abstract}

\section{Personal Perspective}

Having worked in the area of cancer research for over a decade, the major focus of one of the authors' investigations has been to develop therapeutic solutions by using siRNA to directly inhibit growth of tumors [1], and to stimulate tumor immunity using antigen-specific vaccines [2-4] or unorthodox immune-modulatory approaches [5-9]. Not until the author's mother passed away from leukemia did he realize that, while many options have been developed in the treatment of cancers, relatively little can be performed at end-of-life. While life support technologies have significantly increased life span, the quality of life at end stages can be devastatingly poor. The author (whose training was in the basic research space) was surprised to realize that, for the majority of cancers, the patient is literally "waiting to die" while on various supportive measures.

This led to the realization that there is a major need for supportive steps that: increase the quality of life, "do no harm", and hold out the possibility (however slim) of restoring some measure of lost life functions back to

\footnotetext{
* Correspondence: nhriordan@gmail.com

'Department of Orthomolecular Studies, Riordan Clinic, 3100 N Hillside, Wichita, Kansas, 67210, USA

Full list of author information is available at the end of the article
}

patients. One intervention that caught the attention of the author while at his mother's bedside was the practice of intravenous ascorbic acid (IV AA) administration $[10,11]$. That specific intervention was supported by a report in the literature that intravenous administration of AA ( $10 \mathrm{~g}$ twice and $4 \mathrm{~g}$ daily orally for one week)significantly increased the quality of life in end stage patients [12]. Could such an easy-to-implement therapy actually be of benefit to patients facing the same challenges of the deceased mother of the author?

When the author discussed this option with others, it became evident that the value of i.v. AA in cancer treatment is controversial. In the $1970 \mathrm{~s}$ work by Cameron and Pauling demonstrated an approximate 4-fold survival increase in terminal cancer patients administered AA by i.v. and oral routes, compared to historical controls $[13,14]$, a finding that was also observed in the results of a trial published by Murata et al. [15]. Subsequent trials that did not use historical controls but had a double-blind placebo-controlled design failed to find benefit $[16,17]$. The controversy has continued with recent reports that oral AA administration, which was used in the trials that failed to demonstrate benefit, fails to increase plasma concentrations to a level estimated to be sufficient to induce tumor cytotoxicity [18-24].
C Biomed Central

() 2011 Ichim et al; licensee BioMed Central Ltd. This is an Open Access article distributed under the terms of the Creative Commons Attribution License (http://creativecommons.org/licenses/by/2.0), which permits unrestricted use, distribution, and reproduction in any medium, provided the original work is properly cited. 
Currently, i.v. AA is used extensively by "alternative medicine" practitioners in the USA (11,233 patients treated in 2006 and 8876 patients in 2008) [25], although the basis for this practice has not been adopted into mainstream medicine. It is our belief that, in the practice of medicine, opinion should not hold greater weight than evidence - either a treatment has beneficial effects or it does not, and it is that consideration that must drive practice. We therefore sought, not to address the controversial area of whether AA shrinks tumors (which is currently being addressed in ongoing FDA approved trials [26-31]), but instead in an area that we feel has been highly under-explored: that is, suppression of inflammation in the cancer patient. In the context of cancer, inflammation may be seen as a continuum of possible degrees of severity ranging from low level, chronic inflammatory response to acute, highly severe inflammation. At the chronic end, low grade inflammation causes a variety of pathologies to the patient, perhaps most profound of which is cachexia [32-35], but also other effects such as poor post-surgical outcomes $[36,37]$. At the other end of the spectrum is the acute inflammation observed in the systemic inflammatory response syndrome (SIRS), a major cause of death of cancer patients and especially patients with hematological malignancies [38-40]. While we focus in this paper on SIRS and cancer, some of the concepts discussed are also applicable to chronic inflammatory conditions.

\section{What is SIRS?}

According to the accepted definition, Systemic Inflammatory Response Syndrome (SIRS) is a term characterizing an inflammatory syndrome caused by infectious or traumatic causes in which patients exhibit at least 2 of the following criteria: 1) Body temperature less than $36^{\circ}$ $\mathrm{C}$ or greater than $38^{\circ} \mathrm{C}$; 2) Heart rate greater than 90 beats per minute; 3)Tachypnea, with greater than 20 breaths per minute; or, an arterial partial pressure of carbon dioxide less than $4.3 \mathrm{kPa}(32 \mathrm{mmHg}$ : 4) White blood cell count less than 4000 cells $/ \mathrm{mm}^{3}(4 \times 109$ cells/L) or greater than 12,000 cells $/ \mathrm{mm}^{3}(12 \times 109$ cells/L); or the presence of greater than $10 \%$ immature neutrophils (band forms) [41]. SIRS is different than sepsis in that in sepsis an active infection is found [42]. These patients may progress to acute kidney or lung failure, shock, and multiple organ dysfunction syndrome. The term septic shock refers to conditions in which the patient has a systolic blood pressure of less than 90 $\mathrm{mmHg}$ despite sufficient fluid resuscitation and administration of vasopressors/inotropes.

Predominant events in the progression to SIRS and subsequently to MOF include: a) systemic activation of inflammatory responses [43]; b) endothelial activation and initiation of the clotting cascade, associated with consumption of anticoagulants and fibrinolytic factors [44]; c) complement activation [45]; and d) organ failure and death. These pathological events appear to be related to each other, for example, it is known that complement activation stimulates the pro-coagulant state [46]. In the cancer patient SIRS may be initiated by several factors. Numerous patients receive immune suppressive chemo/radiotherapies that promote opportunistic infections $[47,48]$. Additionally, given that approximately $40-70 \%$ of patients are cachectic, the low grade inflammation causing the cachexia could augment effects of additional bacterial/injury-induced inflammatory cascades [49]. Finally, tumors themselves, and through interaction with host factors, have been demonstrated to generate systemically-acting inflammatory mediators such as IL-1, IL-6, and TNF-alpha that may predispose to SIRS [50,51].

Current SIRS treatments SIRS are primarily supportive. To date, the only drug to have elicited an effect on SIRS in Phase III double-blind, placebo-controlled trials has been Xigris (activated protein C (APC)) [52], which exerts its effects by activating endothelial cell-protecting mechanisms mediating protection against apoptosis, stimulation of barrier function through the angiopoietin/ Tie- 2 axis, and by reducing local clotting [53-55]. The basis of approval for Xigris has been questioned by some [56] and, additionally, it is often counter-indicated in oncology-associated sepsis (especially leukemias where bleeding is an issue of great concern). In fact, in the Phase III trials of Xigris, hematopoietic transplant patients were excluded [57]. Thus there is a great need for progress in the area of SIRS treatment and adjuvant approaches for agents such as Xigris.

\section{Endothelial Dysfunction of SIRS}

One of the main causes of death related to SIRS is dysfunction of the microcirculatory system, which in the most advanced stages is manifested as disseminated intravascular coagulation (DIC) [44]. Inflammatory mediators associated with SIRS, whether endotoxin or injury-related signals such as TLR agonists or HMGB-1, are all capable of activating endothelium systemically $[58,59]$. Under physiological conditions, the endothelial response to such mediators is local and provides a useful mechanism for sequestering an infection and allowing immune attack. In SIRS, the fact that the response is systemic causes disastrous consequences includingorgan failure. The characteristics of this endothelial response include: a) upregulation of tissue factor (TF) $[60,61]$ and suppression of endothelial inhibitors of coagulation such as protein $C$ and the antithrombin system causing a pro-coagulant state [62]; b) increased expression of adhesion molecules which elicit, in turn, neutrophil extravasation [63]; c) decreased fibrinolytic capacity 
[64-66]; and d) increased vascular permeability/nonresponsiveness to vaso-dilators and vasoconstrictors $[67,68]$. Excellent detailed reviews of molecular signals associated with SIRS-induced endothelial dysfunction have been published [69-77] and one of the key factors implicated has been NF-kB [78]. Nuclear translocation of NF-kB is associated with endothelial upregulation of pro-thrombotic molecules and suppressed fibrinolysis [79-81]. In an elegant study, Song et al. inhibited NF-kB selectively in the endothelium by creation of transgenic mice transgenic expressing exogenous i-kappa $B$ (the NF-kB inhibitor) specifically in the vasculature. In contrast to wild-type animals, the endothelial cells of these transgenic mice experienced substantially reduced expression of tissue factor while retaining expression of endothelial protein $\mathrm{C}$ receptor and thrombomodulin subsequent to endotoxin challenge. Furthermore, expression of NF-B was associated with generation of TNF-alpha as a result of TACE activity [82].

It is interesting that the beneficial effects of Xigris in SIRS appear to be associated with its ability to prevent the endothelial dysfunction [83] associated with suppression of proinflammatory chemokines [84], prevention of endothelial cell apoptosis [85], and increased endothelial fibrinolytic activity $[86,87]$. Some of the protective activities of Xigris have been ascribed to its ability to suppress NF-kB activation in endothelial cells $[88,89]$.

\section{Ascorbic Acid Effects on Endothelium}

Several clinical studies have supported the possibility that AA mediates a beneficial effect on endothelial cells, especially in the context of chronic stress. Heitzer et al. [90] examined acetylcholine-evoked endothelium-dependent vaso-responsiveness in 10 chronic smokers and 10 healthy volunteers. While responsiveness was suppressed in smokers, administration of intra-arterial ascorbate was capable of augmenting reactivity: an augmentation evident only in the smokers. Endothelial stress induced in 17 healthy volunteers by administration of L-methionine led to decreased responsiveness to hyperemic flow and increased homocysteine levels. Oral AA (1 g/day) restored endothelial responsiveness [91]. Restoration of endothelial responsiveness by AA has also been reported in patients with insulin-dependent [92] and independent diabetes [93], as well as chronic hypertension [94]. In these studies AA was administered intraarterially or intravenously, and the authors proposed the mechanism of action to be increased nitric oxide (NO) as a result of AA protecting it from degradation by reactive oxygen species (ROS).

A closer look at the literature suggests that there are several general mechanisms by which AA may exert endothelial protective properties. The importance of basal production of $\mathrm{NO}$ in endothelial function comes from its role as a vasodilator, and an inhibitor of platelet aggregation $[95,96]$. High concentrations of NO are pathological in SIRS due to induction of vascular leakage [97]. However, lack of $\mathrm{NO}$ is also pathological because it causes loss of microvascular circulation and endothelial responsiveness $[98,99]$. Although there are exceptions, the general concept is that inducible nitric oxide synthase (iNOS) and neuronal nitric oxide synthase (nNOS) are associated with sepsis-induced pathologies, whereas eNOS is associated with protective benefits [100]. It is important to note that, while iNOS expression occurs in almost all major cells of the body in the context of inflammation, eNOS is constitutively expressed by the endothelium. AA administration decreases iNOS in the context of inflammation $[101,102]$, but appears to increase eNOS [103]. Thus, AA appears to increase local NO concentrations through: a) prevention of ROS-mediated NO inactivation $[104,105]$; b) increased activity of endothelial-specific nitric oxide synthase (eNOS) [106], possibly mediated by augmenting bioavailability of tetrahydrobiopterin [107-112], a co-factor of eNOS [113]; and c) induction of NO release from plasma-bound S-nitrosothiols [103].

In addition to deregulation of NO, numerous other endothelial changes occur during SIRS, including endothelial cell apoptosis, upregulation of adhesion molecules, and the procoagulant state [114]. AA has been reported to be active in modulating each of these factors. Rossig et al. reported that in vitro administration of AA led to reduction of TNF-alpha induced endothelial cell apoptosis [109]. The effect was mediated in part through suppression of the mitochondriainitiated apoptotic pathway as evidenced by reduced caspase- 9 activation and cytochrome c release. To extend their study into the clinical realm, the investigators prospectively randomized 34 patients with NYHA class III and IV heart failure to receive AA or placebo treatment. AA treatment $(2.5 \mathrm{~g}$ administered intravenously and 3 days of $4 \mathrm{~g}$ per day oral AA) Resulted in reduction in circulating apoptotic endothelial cells in the treated but not placebo control group [115]. Various mechanisms for inhibition of endothelial cell apoptosis by AA have been proposed including upregulation of the anti-apoptotic protein bcl-2 [116] and the $\mathrm{Rb}$ protein, suppression of p53 [117], and increasing numbers of newly formed endothelial progenitor cells [118].

AA has been demonstrated to reduce endothelial cell expression of the adhesion molecule ICAM-1 in response to TNF-alpha in vitro in human umbilical vein endothelial (HUVEC) cells (HUVEC) [119]. By reducing adhesion molecule expression, AA suppresses systemic neutrophil extravasation during sepsis, especially in the lung [120]. Other endothelial effects of AA include 
suppression of tissue factor upregulation in response to inflammatory stimuli [121], and effect expected to prevent the hypercoaguable state. Furthermore, ascorbate supplementation has been directly implicated in suppressing endothelial permeability in the face of inflammatory stimuli [122-124], which would hypothetically reduce vascular leakage. Given the importance of NFkappa B signaling in coordinating endothelial inflammatory changes [79-81], it is important to note that AA at pharmacologically attainable concentrations has been demonstrated to specifically inhibit this transcription factor on endothelial cells [125]. Mechanistically, several pathways of inhibition have been identified including reduction of $\mathrm{i}-\mathrm{kappa} \mathrm{B}$ phosphorylation and subsequent degradation [126], and suppression of activation of the upstream p38 MAPK pathway [127]. In vivo data in support of eventual use in humanshas been reported showing that administration of $1 \mathrm{~g}$ per day AA in hypercholesterolemic pigs results in suppression of endothelial NF-kappa B activity, as well as increased eNOS, NO, and endothelial function [128]. In another porcine study, renal stenosis was combined with a high cholesterol diet to mimic renovascular disease. AA administered i.v. resulted in suppression of NF-kappa B activation in the endothelium, an effect associated with improved vascular function [129].

An important factor in reports of clinical studies of AA is the difference in effects seen when different routes of administration are employed. Supplementation with oral AA appears to have rather minor effects, perhaps due to the rate-limiting uptake of transporters found in the gut. Indeed, maximal absorption of AA appears to be achieved with a single $200 \mathrm{mg}$ dose [130]. Higher doses produce gut discomfort and diarrhea because of effects of ascorbate accumulation in the intestinal lumen [131]. This is why some studies use parenteral administration. An example of the superior biological activity of parenteral versus oral was seen in a study administering AA to sedentary men. Parenteral but not oral administration was capable of augmenting endothelial responsiveness as assessed by a flowmediated dilation assay [132].

\section{Cancer Patients are Deficient in Ascorbic Acid}

The general activity of AA as an anti-oxidant implies that conditions associated with chronic inflammation and oxidative stress would lead to its depletion. As reviewed by McGregor and Biesalski [133], numerous inflammatory conditions including gastritis [134], diabetes [134,135], pancreatitis [136], pneumonia [137], osteoporosis [138], rheumatoid arthritis [139], are all associated with marked reduction in plasma AA levels as compared to healthy controls. Within the context of this discussion, profound reduction of AA is observed in cancer patients [140-146], SIRS patients [147], and ICU patients [134].

Some studies have demonstrated correlation between plasma AA and survival. Mayland et al. [141] measured plasma AA in 50 end-stage cancer patients in a hospice setting. A correlation between deficiency in AA, decreased survival, and higher expression of the inflammatory marker CRP was noted. More recently, a correlation between tumor aggressiveness and low AA content has been made [148]. Kuiper et al. found that the proangiogenic transcription factor HIF-1 alpha is negatively correlated with tumor AA content. Correlations where also made between low AA content, high VEGF, and levels of the anti-apoptotic protein bcl-2.

Cancer patients are known to exhibit a general state of chronic inflammation which, as stated above, is related to the tumor itself and the interaction of host factors with the tumor. Elevation in the level of classical inflammatory markers such as fibrinogen [149-155], CRP [156-160], erythrocyte sedimentation rate [161], ferritin [162-165], neopterin [166-168], homocysteine $[169,170]$, IL-6 [161,171], and free radical stress [172-175] have been well-documented in cancer patients, with numerous studies demonstrating that elevation is associated with poor survival.

The possibility that inflammation itself reduces plasma AA was shown by Fain et al. [176], who examined 184 hospitalized patients and observed that $47.3 \%$ suffered from hypovitaminosis $\mathrm{C}$ as defined as either depletion $(i$. e., serum AA levels $<5 \mathrm{mg} / \mathrm{l}$ ) or deficiency (i.e., serum AA levels $<2 \mathrm{mg} / \mathrm{l})$. Interestingly, patients with an activated acute phase response, as defined by erythrocyte sedimentation rate above $20 \mathrm{~mm}$ and an increase in acute phase reactants (CRP $>10 \mathrm{mg} / \mathrm{l}$ and/or fibrinogen $>4 \mathrm{~g} / \mathrm{l}$ ) had lower serum AA levels. Also associated with decreased serum AA levels was reduction in hemoglobin and albumin. A Japanese population study of 778 men and 1404 women, aged 40-69 years, demonstrated a negative correlation between plasma AA content and CRP [177]. In an interventional study, Block et al. examined 396 healthy nonsmokers randomized to receive either $1000 \mathrm{mg} /$ day vitamin C, $800 \mathrm{IU} /$ day vitamin E, or placebo, for 2 months. A statistically significant decrease in plasma CRP levels was found only in the group receiving AA [178].

While a study by Mayland et al. demonstrated that, in 50 patients with advanced malignancies of various types, a correlation between high CRP levels and AA deficiency existed [179], to our knowledge no interventional studies in cancer patients have been performed to assess the capacity of AA administered i.v. to inhibit chronic inflammation. In the absence of such studies, we looked at reports of AA inhibition ofs inflammatory markers in the context of other diseases to determine whether a 
rationale may exist for its use in cancer. Several such supporting studies exist. Administration of IV AA has been shown to decrease CRP levels in smokers [180]. Oral AA supplementation decreased CRP levels in a trial of 44 patients suffering from atrial fibrillation after cardioversion [181]. In a study of 12 healthy volunteers, it was shown that i.v. AA inhibited endothelin-induced IL-6 production [182]. In a study of 1463 coronary artery disease patients, a negative correlation between neopterin (a catabolic product of GTP indicative of immune activation) and AA concentration was noted [183]. Given that there are, at present, numerous trials being conducted using i.v. AA in the treatment of cancer [26-31], it is highly unfortunate that none of them are assessing inflammatory markers or other potential mechanisms of action. This may, to some degree, be detrimental to future study of AA in cancer treatment: if poor tumor regression data is generated, replication of these trials with inclusion of sensitive inflammatory marker endpoints may never occur.

\section{SIRS patients are deficient in AA}

The progression of SIRS into MOF is perhaps one of the most inflammation-driven disease pathologies. If the overall hypothesis that AA is consumed by inflammation is correct, these patients should be highly deficient. This appears to be the case: several studies have demonstrated severe deficiency in AA in patients with sepsis and septic shock compared to healthy volunteers. Doise et al. examined 37 patients with septic shock, 19 patients with severe sepsis, and 6 healthy volunteers over the period of 10 days. A significant deficiency of AA was observed compared to controls, and blood AA levels continued to decline while the patients were in the ICU. No difference between the deficiency in septic shock and severe sepsis was noted [184]. The association ofAA deficiency with poor outcomes was further strengthened in a study of 16 ICU patients in which a statistically significant decrease in AA was found in patients progressing to MOF [185]. Indeed, septic patients have been demonstrated to exhibit a much higher rate of ascorbate consumption compared to healthy volunteers, based on studies in which predefined doses of AA were administered and in vivo degradation and disappearance was assessed [186].

Animal models suggest a critical role for AA in protecting from/inhibiting the septic process. In an elegant study, mice deficient for ascorbic acid synthesis (i.e., deficient in L-gulono-gamma-lactone oxidase) were depleted of exogenous ascorbate by feeding on an ascorbate-free diet and challenge with the pathogen Klebsiella pneumonia. Mortality was 3 -fold higher in ascorbatedeficient animals compared to controls, which received a standard ascorbate-containing diet [187]. Given that cancer patients are generally deficient in AA, these findings may suggest the importance of maintaining at least normal AA levels to prevent from onset of SIRS [140-146]. Supplementation with AA has been demonstrated to protect against sepsis-associated death. Using a "feces injection into the peritoneum" model of sepsis, i.v. injection of $10 \mathrm{mg} / \mathrm{kg}$ AA resulted in $50 \%$ survival, in contrast to a $19 \%$ survival in animals receiving saline [98]. Supplementation with AA improved outcome in sepsis-associated hypoglycemia [188], microcirculatory abnormalities [189], and blunted endothelial responsiveness $[101,102,190]$ in animal models.

From a clinical perspective, Crimi et al. reported a prospective randomized study in which vitamins $C(500$ $\mathrm{mg} / \mathrm{d})$ and $\mathrm{E}(400 \mathrm{IU} / \mathrm{d})$ where administered via enteral tube to a group of 105 critically ill patients, whereas a control group of 111 patients received a isocaloric formula without supplementation with these vitamins. At patient follow-up, reduced TBARS and isoprostanes (markers of oxidative stress) were observed in the treated group. In addition, improved survival at 28 days of treatment was reported: $54.3 \%$ in the antioxidant group and $32.5 \%$ in the regular-feeding group $(p<0.05)$ [191]. Nathens et al. performed a larger study of 595 critically ill surgical patients where the majority suffered from trauma. AA and vitamin $\mathrm{E}$ where administered i.v. 3 times per day (1000 mg per injection and $1000 \mathrm{IU}$ enterally, respectively). Reductions in the time of hospital stay, pulmonary mortality, and need for mechanical ventilation was observed in the treated group. Furthermore, MOF incidence was reduced in the anti-oxidant supplemented group [192]. In a study of the effect of AA alone in treatment of burn patients with $>30 \%$ of their total body surface area affected, patients were given AA i.v. $(66 \mathrm{mg} / \mathrm{kg} / \mathrm{hr}$ for 24 hours, $\mathrm{n}=19)$ or received only standard care (controls, $\mathrm{n}=18$ ). AA treatment resulted in statistically significant reductions in $24 \mathrm{hr}$ total fluid infusion volume, fluid retention (indicative of vascular leakage), and MDA. Perhaps most striking was the decrease in the need for mechanical ventilation: the treated group required an average of $12.1 \pm 8.8$ days, while the control group required $21.3 \pm 15.6$ days [193].

Thus it appears that cancer patients generally have a deficiency in AA which may predispose to SIRS and subsequent MOF, and patients with other diseases exhibit symptom severity inversely associated with AA levels. Patients who do develop SIRS and MOF have even greater depletion of AA and, as a result, various changes in the endothelium occur which exacerbate progression to mortality. Thus, there is some rationale for use of AA in cancer patients to prevent/treat SIRS. There is an additional possible benefit in that AA may actually inhibit cancer initiation and growth. Without providing an exhaustive review of this controversial 
subject, we will touch upon some work that has been performed in this area.

\section{AA Effects in Cancer}

The state of AA deficiency in cancer patients, whether or not as a result of inflammation, suggests that supplementation may yield benefit in quality of life. Indeed, this was one of the main findings that stimulated us to write this review [12]. Improvements in quality of life were also noted in the early studies of Murata et al. [15] and Cameron [11]. But, in addition to this endpoint, there appears to be a growing number of studies suggesting direct anti-cancer effects via generation of free radicals locally at tumor sites [21]. In vitro studies on a variety of cancer cells including neuroblastoma [194], bladder cancer [195], pancreatic cancer [196], mesothelioma [197], and hepatoma [198], have demonstrated cytotoxic effects at pharmacologically-achievable concentrations. Enhancement of cytotoxicity of docetaxel, epirubicin, irinotecan, and 5-FU to a battery of tumor cell lines by AA was demonstrated in vitro [199]. In vivo studies have also supported the potential anticancer effects of AA. For example, Pollard et al. used the rat PAIII androgen-independent syngeneic prostate cancer cell line to induce tumors in Lobund-Wistar rats. Daily intraperitoneal administration of AA for 30 days (with evaluation at day 40) revealed significant inhibition of tumor growth and reduction in pulmonary and lymphatic metastasis [200]. Levine's group reported successful in vivo inhibition of human xenografted glioma, overian, and neuroblastoma cells in immune-deficient animals by administration of AA. Interestingly, control fibroblasts were not affected [23]. Clinical reports of remission induced by i.v. AA have been published [201]. However, as mentioned above, formal trials are still ongoing. Table 1 summarizes previous trials.

In addition to direct cytotoxicity of AA on tumor cells, inhibition of angiogenesis may be another mechanism of action. It has been reported that AA inhibits HUVEC proliferation in vitro [202] and suppresses neovascularization in the chorionic allontoic membrane assay [203]. We recently reported that in vivo administration of AA suppresses vascular cord formation in mouse models [204]. Supporting this, Yeom et al. demonstrated that parenteral administration of AA in the S-180 sarcoma cell model leads to reduced tumor growth, which was associated with suppression of angiogenesis and reduced expression of the pro-angiogenic factors bFGF, VEGF, and MMP-2 [205]. Recent studies suggest that AA suppresses activation of the hypoxiainducible factor (HIF)- 1 , which is a critical transcription factor that stimulates tumor angiogenesis [206-208]. The clinical relevance of this has been demonstrated in a study showing that endometrial cancer patients with reduced tumor ascorbate levels have higher levels of active HIF-1 and a more aggressive phenotype [148].

Thus the possibility exists that administration of AA for treatment of tumor inflammation-mediated pathologies may also cause an antitumor effect. Whether this effect is mediated by direct tumor cytotoxicity or inhibition of angiogenesis remains to be determined. Unfortunately, none of the ongoing trials of AA in cancer patients seek to address this issue [26-31].

\section{Areas needing study: AA and Immunity}

Despite numerous claims in the popular media (and even on labels on over-the-counter vitamin packaging), AA stimulation of immune function to reduce tumor initiation and growth is not clear-cut. This is partly because ROS are involved in numerous signaling events in immune cells [209]. For example, it is known that $\mathrm{T}$ cell receptor signaling induces an intracellular flux of ROS which is necessary for $\mathrm{T}$ cell activation [210]. There are also numerous studies demonstrating that ascorbic acid, under certain conditions, can actually inhibit immunity. For example, high dose ascorbate inhibits $\mathrm{T}$ cell and $\mathrm{B}$ cell proliferative responses as well as IL-2 secretion in vitro [211,212], and NK cytotoxic activity [213]. In addition, AA has been demonstrated to inhibit $\mathrm{T}$ cell activation of dendritic cells by encouraging them to remain in an immature state, in part through inhibition of NF-kappa B [214].

It is possible, although not formally tested, that the immune stimulatory effects of AA are actually observed in the context of background immune suppression or in situations of AA deficiency, both of which are wellknown in the cancer and SIRS patient. Cleavage of the $\mathrm{T}$ cell receptor (TCR) zeta chain is a common occurrence in cancer [215-219] and SIRS patients [220,221]. The zeta chain is an important functional factor in $\mathrm{T}$ cell and NK cell activation, and is the most highly expressed of the immunoreceptor tyrosine-based activation motifs (ITAMs) on T and NK cells [222]. At the cellular level, cleavage of the zeta chain is associated with loss of T/NK cell function and spontaneous apoptosis [223-225] and, in the clinic, it is associated with poor prognosis [226-231].

Since loss of the TCR zeta chain is found in other inflammatory conditions ranging from hemodialysis [232,233], to autoimmunity [234-237], to heart disease [238], the possibility that inflammatory mediators such as ROS cause TCR zeta downregulation has been suggested. Circumstantial evidence comes from studies correlating presence of inflammatory cells such as tumor-associated macrophages with suppression of zeta chain expression [239]. Myeloid suppressor cells (which are known to produce high concentrations of ROS [240-242]) have also been demonstrated to induce reduction of TCR zeta chain 
Table 1 Ascorbic Acid Cancer Trials

\begin{tabular}{|c|c|c|c|c|}
\hline Condition & Number of Patients & Dose/Route & Finding & Ref \\
\hline $\begin{array}{l}\text { Mixture of solid } \\
\text { tumors at } \\
\text { different stages }\end{array}$ & 49 & $\begin{array}{l}\text { Intravenous for } 10 \text { days } 10 \mathrm{~g} \text { and } \\
\text { subsequently daily oral } 10 \mathrm{~g} / \text { day }\end{array}$ & $\begin{array}{l}17 \text { pts no response, } 10 \text { pts minimal response, } \\
11 \text { pts growth retardation, } 2 \text { pts cytostasis, } 5 \text { pts } \\
\text { tumor regression, } 4 \text { pts tumor hemorrhage/ } \\
\text { necrosis }\end{array}$ & 11 \\
\hline $\begin{array}{l}\text { Terminal cancer } \\
\text { patients }\end{array}$ & 39 & $\begin{array}{l}\text { Intravenous } 10 \mathrm{~g} \text { vitamin } \mathrm{C} \text { twice } \\
\text { with a 3-day interval and an oral } \\
\text { intake of } 4 \mathrm{~g} \text { vitamin C daily for a } \\
\text { week }\end{array}$ & $\begin{array}{l}\text { Health score improved from } 36+/-18 \text { to } 55+/-16 \\
(p=0.001) \text {. Significantly higher scores for } \\
\text { physical, role, emotional, and cognitive function } \\
(p<0.05) \text {. In symptom scale, the patients } \\
\text { reported significantly lower scores for fatigue, } \\
\text { nausea/vomiting, pain, and appetite loss } \\
(p<0.005) \text {. }\end{array}$ & 12 \\
\hline $\begin{array}{l}\text { Terminal cancer } \\
\text { patients }\end{array}$ & $\begin{array}{l}100 \text { cancer pts treated as compared } \\
\text { to } 1000 \text { controls. } 50 \text { of the treated pts } \\
\text { were in the publication described in } \\
\text { ref } 11 .\end{array}$ & $\begin{array}{l}\text { Intravenous for } 10 \text { days } 10 \mathrm{~g} \text { and } \\
\text { subsequently daily oral } 10 \mathrm{~g} / \text { day }\end{array}$ & $\begin{array}{l}\text { Mean survival time }>4.2 \text { times as great for the } \\
\text { ascorbate subjects (more than } 210 \text { days) as for } \\
\text { the controls ( } 50 \text { days). Survival-time curves } \\
\text { indicate that deaths occur for about } 90 \% \text { of the } \\
\text { ascorbate-treated patients at one-third the rate } \\
\text { for the controls and that the other } 10 \% \text { have a } \\
\text { much greater survival time, averaging more } \\
\text { than } 20 \text { times that for the controls. }\end{array}$ & 13 \\
\hline $\begin{array}{l}\text { Terminal cancer } \\
\text { patients }\end{array}$ & $\begin{array}{l}99 \text { in one hospital and } 31 \text { in another } \\
\text { hospital }\end{array}$ & $30 \mathrm{~g} /$ day intravenously & $\begin{array}{l}\text { Hospital \#1: Survival of } 43 \text { days for } 44 \text { low- } \\
\text { ascorbate patients and } 246 \text { days for } 55 \text { high- } \\
\text { ascorbate patients. } \\
\text { Hospital \#2: } 48 \text { days for } 19 \text { control patients and } \\
115 \text { days for } 6 \text { high-ascorbate patients. }\end{array}$ & 15 \\
\hline $\begin{array}{l}\text { Terminal cancer } \\
\text { patients }\end{array}$ & 60 AA, 63 placebo controlled & 10 g/day oral & $\begin{array}{l}\text { The two groups showed no appreciable } \\
\text { difference in changes in symptoms, } \\
\text { performance status, appetite or weight. The } \\
\text { median survival for all patients was about seven } \\
\text { weeks, and the survival curves essentially } \\
\text { overlapped. }\end{array}$ & 16 \\
\hline $\begin{array}{l}\text { Advanced } \\
\text { colorectal } \\
\text { cancer }\end{array}$ & $50 \mathrm{AA}, 50$ control & 10 g/day oral & $\begin{array}{l}\text { AA treatment had advantage over placebo with } \\
\text { regard to either the interval between the } \\
\text { beginning of treatment and disease progression } \\
\text { or patient survival. Among patients with } \\
\text { measurable disease, none had objective } \\
\text { improvement. }\end{array}$ & 17 \\
\hline $\begin{array}{l}\text { Renal } \\
\text { metastatic, B } \\
\text { cell lymphoma, } \\
\text { Bladder cancer }\end{array}$ & 3 Cases & $\begin{array}{l}50-100 \mathrm{~g} \text { intravenously, various } \\
\text { regimens }\end{array}$ & $\begin{array}{l}\text { Tumor regression and unexpectedly long } \\
\text { survival. }\end{array}$ & 201 \\
\hline
\end{tabular}

in cancer [243], and after trauma [244]. Administration of anti-oxidants has been shown to reverse TCR zeta chain cleavage in tissue culture $[245,246]$. Therefore, from the $\mathrm{T}$ cell side of immunity, an argument could be made that intravenous ascorbic acid may upregulate immunity by blocking zeta chain downregulation in the context of cancer and acute inflammation.

While it is known that AA functions as an antioxidant in numerous biological conditions, as well as reduces inflammatory markers, the possibility that AA actually increases immune function in cancer patients has never been formally tested. This is an area that in our opinion cries out for further studies.

\section{Conclusion}

AA administered intravenously has a long and controversial history in relation to reducing tumors in patients.
This has impeded research into other potential benefits of this therapy in cancer patients such as reduction of inflammation, improvement of quality of life, and reduction ofSIRS initiation and progression to MOF. While ongoing clinical trials of i.v. AA for cancer may or may not meet the bar to grant this modality a place amongst the recognized chemotherapeutic agents, it is critical that we collect as much biological data as possible, given the possibility of this agent to be a wonderful adjuvant therapy.

\section{Acknowledgements}

This work was supported by Allan P Markin. The paper is dedicated to Florica Batu Ichim, who passed away September $4^{\text {th }}, 2010$ after a 23 year battle with leukemia, and to Drs Jeffrey Lipton, Hans Messner, Mark Minden and the Team at Princess Margaret Hospital who cared for her for over two decades. 


\section{Author details}

'Department of Orthomolecular Studies, Riordan Clinic, 3100 N Hillside Wichita, Kansas, 67210, USA. ²Department of Regenerative Medicine, Medistem Inc, 9255 Towne Centre Drive, San Diego, California, 92121. USA. ${ }^{3}$ Department of Medicine, Moores Cancer Center, University of California San Diego, 3855 Health Sciences Dr, San Diego, California, 92121, USA. ${ }^{4}$ Department of Immunology, Torrey Pines Institute for Molecular Studies, 3550 General Atomics Court, La Jolla, California,92121, USA. ${ }^{5}$ Department of Human Development, Nutrition Program, University of Puerto Rico, Medical Sciences Campus, San Juan, 00936-5067, PR. ${ }^{6}$ Department of Pharmacy Practice, University of Puerto Rico, Medical Sciences Campus, School of Pharmacy, San Juan, 00936-5067, PR. 'Department of Experimental Studies, Georgetown Dermatology, 3301 New Mexico Ave, Washington DC, 20018, USA. ${ }^{8}$ Department of Hematology and Oncology, University of Connecticut, 115 North Eagleville Road, Hartford, Connecticut, 06269, USA. ${ }^{9}$ Department of Surgery, University of Latvia, 19 Raina Blvd, Riga, LV 1586, Latvia. ${ }^{10}$ Department of Surgery, Microbiology, and Pathology, University of Nebraska Medical Center, 42nd and Emile, Omaha, Nebraska, 86198, USA.

${ }^{11}$ Department of Microbiology and Immunology, and Department of Oncology, Lawson Health Research Institute and The University of Western Ontario, 1151 Richmond Street, London, Ontario, N2G 3M5, Canada. ${ }^{12}$ School of Medicine, Division of Hematology and Oncology, Loma Linda University,24851 Circle Dr, Loma Linda, California, 92354, USA.

\section{Authors' contributions}

TEl, BM, TB, BL, RH, NAM, JAJ, MJG, JRMM, DTA, CD, VB, JA, RBS, BM, JK, CSC, $\mathrm{NHR}$ all contributed to the development of the concept, literature review, discussions, and writing of the manuscript. All authors have read the manuscript and agree to its submission.

\section{Competing interests}

The authors declare that they have no competing interests.

Received: 13 December 2010 Accepted: 4 March 2011 Published: 4 March 2011

\section{References}

1. Dougherty CJ, Ichim TE, Liu L, Reznik G, Min WP, Ghochikyan A, Agadjanyan MG, Reznik BN: Selective apoptosis of breast cancer cells by siRNA targeting of BORIS. Biochem Biophys Res Commun 2008, 370:109-112.

2. Loukinov D, Ghochikyan A, Mkrtichyan M, Ichim TE, Lobanenkov W, Cribbs DH, Agadjanyan MG: Antitumor efficacy of DNA vaccination to the epigenetically acting tumor promoting transcription factor BORIS and CD80 molecular adjuvant. J Cell Biochem 2006, 98:1037-1043.

3. Ghochikyan A, Mkrtichyan M, Loukinov D, Mamikonyan G, Pack SD, Movsesyan N, Ichim TE, Cribbs DH, Lobanenkov W, Agadjanyan MG: Elicitation of T cell responses to histologically unrelated tumors by immunization with the novel cancer-testis antigen, brother of the regulator of imprinted sites. J Immunol 2007, 178:566-573.

4. Mkrtichyan M, Ghochikyan A, Loukinov D, Davtyan H, Ichim TE, Cribbs DH, Lobanenkov W, Agadjanyan MG: DNA, but not protein vaccine based on mutated BORIS antigen significantly inhibits tumor growth and prolongs the survival of mice. Gene Ther 2008, 15:61-64.

5. Ichim TE, Zhong Z, Kaushal S, Zheng X, Ren X, Hao X, Joyce JA, Hanley HH, Riordan $\mathrm{NH}$, Koropatnick J, et al: Exosomes as a tumor immune escape mechanism: possible therapeutic implications. J Trans/ Med 2008, 6:37.

6. Marleau AM, Lipton JH, Riordan NH, IChim TE: Therapeutic use of Aldara in chronic myeloid leukemia. J Trans/ Med 2007, 5:4.

7. Ichim TE, Popov IA, Riordan NH, Izadi H, Zhong Z, Yijian L, Sher S, Oleinik EK: A novel method of modifying immune responses by vaccination with lipiodol-siRNA mixtures. J Transl Med 2006, 4:2.

8. Zhong Z, Kusznieruk KP, Popov IA, Riordan NH, Izadi H, Yijian L, Sher S, Szczurko OM, Agadjanyan MG, Tullis RH, et al: Induction of antitumor immunity through xenoplacental immunization. J Trans/ Med 2006, 4:22.

9. Han X, Meng X, Yin Z, Rogers A, Zhong J, Rillema P, Jackson JA, Ichim TE, Minev $B$, Carrier $E$, et al: Inhibition of intracranial glioma growth by endometrial regenerative cells. Cell Cycle 2009, 8:606-610.

10. Levenson SM, et al: Ascorbic acid $r$, thiamin, and nicotinic acid in relation to severe injury, hemorrhage, and infection in the human. Ann Surg 1946, 124:840-856.
11. Cameron E, Campbell A: The orthomolecular treatment of cancer. II. Clinical trial of high-dose ascorbic acid supplements in advanced human cancer. Chem Biol Interact 1974, 9:285-315.

12. Yeom CH, Jung GC, Song KJ: Changes of terminal cancer patients' healthrelated quality of life after high dose vitamin C administration. J Korean Med Sci 2007, 22:7-11.

13. Cameron E, Pauling L: Supplemental ascorbate in the supportive treatment of cancer: Prolongation of survival times in terminal human cancer. Proc Natl Acad Sci USA 1976, 73:3685-3689.

14. Cameron and Pauling PNASUSAS-Saitstocropos.

15. Murata A, Morishige F, Yamaguchi H: Prolongation of survival times of terminal cancer patients by administration of large doses of ascorbate. Int J Vitam Nutr Res Suppl 1982, 23:103-113.

16. Creagan ET, Moertel CG, O'Fallon JR, Schutt AJ, O'Connell MJ, Rubin J, Frytak S: Failure of high-dose vitamin C (ascorbic acid) therapy to benefit patients with advanced cancer. A controlled trial. N Engl J Med 1979, 301:687-690.

17. Moertel CG, Fleming TR, Creagan ET, Rubin J, O'Connell MJ, Ames MM: High-dose vitamin $C$ versus placebo in the treatment of patients with advanced cancer who have had no prior chemotherapy. A randomized double-blind comparison. N Engl J Med 1985, 312:137-141.

18. Duconge J, Miranda-Massari JR, Gonzalez MJ, Jackson JA, Warnock W, Riordan NH: Pharmacokinetics of vitamin C: insights into the oral and intravenous administration of ascorbate. $P$ R Health SCi I 2008, 27:7-19.

19. Duconge J, Miranda-Massari JR, Gonzalez MJ, Taylor PR, Riordan HD, Riordan NH, Casciari JJ, Alliston K: Vitamin C pharmacokinetics after continuous infusion in a patient with prostate cancer. Ann Pharmacother 2007, 41:1082-1083.

20. Padayatty SJ, Sun H, Wang Y, Riordan HD, Hewitt SM, Katz A, Wesley RA, Levine M: Vitamin C pharmacokinetics: implications for oral and intravenous use. Ann Intern Med 2004, 140:533-537.

21. Riordan NH, Riordan HD, Meng X, Li Y, Jackson JA: Intravenous ascorbate as a tumor cytotoxic chemotherapeutic agent. Med Hypotheses 1995, 44:207-213.

22. Verrax J, Calderon PB: Pharmacologic concentrations of ascorbate are achieved by parenteral administration and exhibit antitumoral effects. Free Radic Biol Med 2009, 47:32-40.

23. Chen Q, Espey MG, Sun AY, Pooput C, Kirk KL, Krishna MC, Khosh DB, Drisko J, Levine M: Pharmacologic doses of ascorbate act as a prooxidant and decrease growth of aggressive tumor xenografts in mice. Proc Natl Acad Sci USA 2008, 105:11105-11109.

24. Chen Q, Espey MG, Sun AY, Lee JH, Krishna MC, Shacter E, Choyke PL, Pooput C, Kirk KL, Buettner GR, Levine M: Ascorbate in pharmacologic concentrations selectively generates ascorbate radical and hydrogen peroxide in extracellular fluid in vivo. Proc Natl Acad Sci USA 2007, 104:8749-8754

25. Padayatty SJ, Sun AY, Chen Q, Espey MG, Drisko J, Levine M: Vitamin C: intravenous use by complementary and alternative medicine practitioners and adverse effects. PLoS One 5:e11414.

26. Study of High-Dose Intravenous (IV) Vitamin C Treatment in Patients With Solid Tumors. [http://www.clinicaltrials.gov/ct2/show/NCT00441207]

27. Vitamin C as an Anti-cancer Drug. [http://www.clinicaltrials.gov/ct2/show/ NCT01080352].

28. Pilot Trial of Intravenous Vitamin C in Refractory Non-Hodgkin Lymphoma (NHL). [http://www.clinicaltrials.gov/ct2/show/NCT00626444].

29. Study of High Dose Intravenous (IV) Ascorbic Acid in Measurable Solid Tumor Disease. [http://www.clinicaltrials.gov/ct2/show/NCT01125449].

30. Trial of Chemotherapy Plus Intravenous Vitamin C in Patients With Advanced Cancer for Whom Chemotherapy Alone is Only Marginally Effective. [http://www.clinicaltrials.gov/ct2/show/NCT01050621].

31. Intravenous Vitamin C in Combination With Standard Chemotherapy for Pancreatic Cancer. [http://www.clinicaltrials.gov/ct2/show/ NCT00954525].

32. Polterauer S, Grimm C, Seebacher V, Rahhal J, Tempfer C, Reinthaller A, Hefler L: The inflammation-based Glasgow Prognostic Score predicts survival in patients with cervical cancer. Int I Gynecol Cancer 20:1052-1057.

33. Argiles JM, Busquets S, Toledo M, Lopez-Soriano FJ: The role of cytokines in cancer cachexia. Curr Opin Support Palliat Care 2009, 3:263-268.

34. Stephens NA, Skipworth RJ, Fearon KC: Cachexia, survival and the acute phase response. Curr Opin Support Palliat Care 2008, 2:267-274. 
35. Deans C, Wigmore SJ: Systemic inflammation, cachexia and prognosis in patients with cancer. Curr Opin Clin Nutr Metab Care 2005, 8:265-269.

36. Roxburgh CS, McMillan DC: Role of systemic inflammatory response in predicting survival in patients with primary operable cancer. Future Oncol 6:149-163.

37. Lamb GW, McArdle PA, Ramsey S, McNichol AM, Edwards J, Aitchison M, McMillan DC: The relationship between the local and systemic inflammatory responses and survival in patients undergoing resection for localized renal cancer. BJU Int 2008, 102:756-761.

38. Ibrahim S, Claxton DF: SIRS criteria in prediction of septic shock in hospitalized patients with hematologic malignancies. Cancer Biol Ther 2009, 8:1101.

39. Nomura S, Kagawa H, Ozaki Y, Nagahama M, Yoshimura C, Fukuhara S: Relationship between platelet activation and cytokines in systemic inflammatory response syndrome patients with hematological malignancies. Thromb Res 1999, 95:205-213.

40. Regazzoni CJ, Khoury M, Irrazabal C, Myburg C, Galvalisi NR, O'Flaherty M, Sarquis SG, Poderoso JJ: Neutropenia and the development of the systemic inflammatory response syndrome. Intensive Care Med 2003, 29:135-138.

41. American College of Chest Physicians/Society of Critical Care Medicine Consensus Conference: definitions for sepsis and organ failure and guidelines for the use of innovative therapies in sepsis. Crit Care Med 1992, 20:864-874.

42. Systemic Inflammatory Response Syndrome (SIRS) Prognosis. [http:// www.youtube.com/watch?v=p2rEJC7He6g].

43. de Jong HK, van der Poll T, Wiersinga WJ: The systemic pro-inflammatory response in sepsis. J Innate Immun 2:422-430.

44. Gando S: Disseminated intravascular coagulation in trauma patients. Semin Thromb Hemost 2001, 27:585-592.

45. Guo RF, Ward PA: C5a, a therapeutic target in sepsis. Recent Pat Antiinfect Drug Discov 2006, 1:57-65.

46. Silasi-Mansat R, Zhu H, Popescu NI, Peer G, Sfyroera G, Magotti P, Ivanciu L, Lupu C, Mollnes TE, Taylor FB, et al: Complement inhibition decreases the procoagulant response and confers organ protection in a baboon model of Escherichia coli sepsis. Blood 116:1002-1010.

47. Person AK, Kontoyiannis DP, Alexander BD: Fungal infections in transplant and oncology patients. Infect Dis Clin North Am 24:439-459.

48. Kiehn TE: Bacteremia and fungemia in the immunocompromised patient. Eur J Clin Microbiol Infect Dis 1989, 8:832-837.

49. Tisdale MJ: Cancer cachexia. Curr Opin Gastroenterol 26:26-146.

50. Gelin J, Moldawer LL, Lonnroth C, Sherry B, Chizzonite R, Lundholm K: Role of endogenous tumor necrosis factor alpha and interleukin 1 for experimental tumor growth and the development of cancer cachexia. Cancer Res 1991, 51:415-421.

51. Cahlin C, Korner A, Axelsson H, Wang W, Lundholm K, Svanberg E: Experimental cancer cachexia: the role of host-derived cytokines interleukin (IL)-6, IL-12, interferon-gamma, and tumor necrosis factor alpha evaluated in gene knockout, tumor-bearing mice on $\mathrm{C} 57 \mathrm{Bl}$ background and eicosanoid-dependent cachexia. Cancer Res 2000, 60:5488-5493.

52. Ely EW, Bernard GR, Vincent JL: Activated protein $\mathrm{C}$ for severe sepsis. $\mathrm{N}$ Engl J Med 2002, 347:1035-1036.

53. Dhainaut JF, Yan SB, Margolis BD, Lorente JA, Russell JA, Freebairn RC, Spapen HD, Riess H, Basson B, Johnson G, Kinasewitz GT: Drotrecogin alfa (activated) (recombinant human activated protein $\mathrm{C}$ ) reduces host coagulopathy response in patients with severe sepsis. Thromb Haemost 2003, 90:642-653.

54. Minhas N, Xue M, Fukudome K, Jackson CJ: Activated protein C utilizes the angiopoietin/Tie2 axis to promote endothelial barrier function. FASEB J 24:24-873

55. Loubele ST, Spronk HM, Ten Cate H: Activated protein C: a promising drug with multiple effects? Mini Rev Med Chem 2009, 9:620-626.

56. Poole D, Bertolini G, Garattini S: Errors in the approval process and postmarketing evaluation of drotrecogin alfa (activated) for the treatment of severe sepsis. Lancet Infect Dis 2009, 9:67-72.

57. Pastores SM, Papadopoulos E, van den Brink M, Alicea M, Halpern NA: Septic shock and multiple organ failure after hematopoietic stem cell transplantation: treatment with recombinant human activated protein $\mathrm{C}$. Bone Marrow Transplant 2002, 30:131-134.
58. Cristofaro P, Opal SM: The Toll-like receptors and their role in septic shock. Expert Opin Ther Targets 2003, 7:603-612.

59. Treutiger CJ, Mullins GE, Johansson AS, Rouhiainen A, Rauvala HM Erlandsson-Harris H, Andersson U, Yang H, Tracey KJ, Andersson J, Palmblad JE: High mobility group 1 B-box mediates activation of human endothelium. J Intern Med 2003, 254:375-385.

60. Lv B, Wang H, Tang Y, Fan Z, Xiao X, Chen F: High-mobility group box 1 protein induces tissue factor expression in vascular endothelial cells via activation of NF-kappaB and Egr-1. Thromb Haemost 2009, 102:352-359.

61. Wada $H$, Wakita $Y$, Shiku $H$ : Tissue factor expression in endothelial cells in health and disease. Blood Coagul Fibrinolysis 1995, 6(Suppl 1):S26-31.

62. Levi M: The coagulant response in sepsis and inflammation. Hamostaseologie 30:10-12, 14-16.

63. Munro JM, Pober JS, Cotran RS: Recruitment of neutrophils in the local endotoxin response: association with de novo endothelial expression of endothelial leukocyte adhesion molecule-1. Lab Invest 1991, 64:295-299.

64. Lippi G, Ippolito L, Cervellin G: Disseminated intravascular coagulation in burn injury. Semin Thromb Hemost 36:36-429.

65. Lau CL, Zhao Y, Kim J, Kron IL, Sharma A, Yang Z, Laubach VE, Linden J, Ailawadi G, Pinsky DJ: Enhanced fibrinolysis protects against lung ischemia-reperfusion injury. J Thorac Cardiovasc Surg 2009, 137:1241-1248.

66. Levi M, Schouten M, van der Poll T: Sepsis, coagulation, and antithrombin: old lessons and new insights. Semin Thromb Hemost 2008, 34:742-746.

67. Shapiro N, Schuetz P, Yano K, Sorasaki M, Parikh SM, Jones AE, Trzeciak S, Ngo L, Aird WC: The association of endothelial cell signaling, severity of illness, and organ dysfunction in sepsis. Crit Care 14:R182

68. Druey KM, Greipp PR: Narrative review: the systemic capillary leak syndrome. Ann Intern Med 153:153-90.

69. Dejana E, Orsenigo F, Lampugnani MG: The role of adherens junctions and VE-cadherin in the control of vascular permeability. J Cell Sci 2008, 121:2115-2122

70. Azevedo LC, Janiszewski M, Soriano FG, Laurindo FR: Redox mechanisms of vascular cell dysfunction in sepsis. Endocr Metab Immune Disord Drug Targets 2006, 6:159-164.

71. Okajima K: Prevention of endothelial cell injury by activated protein C: the molecular mechanism(s) and therapeutic implications. Curr Vasc Pharmacol 2004, 2:125-133.

72. Andersson U, Tracey KJ: HMGB1 in sepsis. Scand J Infect Dis 2003, 35:577-584.

73. Strassheim D, Park JS, Abraham E: Sepsis: current concepts in intracellular signaling. Int J Biochem Cell Biol 2002, 34:1527-1533.

74. ten Cate H, Schoenmakers SH, Franco R, Timmerman JJ, Groot AP, Spek CA, Reitsma PH: Microvascular coagulopathy and disseminated intravascular coagulation. Crit Care Med 2001, 29:S95-97, discussion 597-98,

75. Hawiger J: Innate immunity and inflammation: a transcriptional paradigm. Immunol Res 2001, 23:99-109.

76. Edgington TS, Mackman N, Fan ST, Ruf W: Cellular immune and cytokine pathways resulting in tissue factor expression and relevance to septic shock. Nouv Rev Fr Hematol 1992, 34(Suppl):S15-27.

77. Mukaida N, Ishikawa Y, Ikeda N, Fujioka N, Watanabe S, Kuno K, Matsushima K: Novel insight into molecular mechanism of endotoxin shock: biochemical analysis of LPS receptor signaling in a cell-free system targeting NF-kappaB and regulation of cytokine production/ action through beta2 integrin in vivo. J Leukoc Biol 1996, 59:145-151.

78. Liu SF, Malik AB: NF-kappa B activation as a pathological mechanism of septic shock and inflammation. Am J Physiol Lung Cell Mol Physiol 2006, 290:L622-L645.

79. Ulfhammer E, Larsson P, Karlsson L, Hrafnkelsdottir T, Bokarewa M, Tarkowski A, Jern S: TNF-alpha mediated suppression of tissue type plasminogen activator expression in vascular endothelial cells is NFkappaB- and p38 MAPK-dependent. J Thromb Haemost 2006, 4:1781-1789.

80. Xu H, Ye X, Steinberg H, Liu SF: Selective blockade of endothelial NFkappaB pathway differentially affects systemic inflammation and multiple organ dysfunction and injury in septic mice. J Pathol 220:220-490.

81. Ding J, Song D, Ye X, Liu SF: A pivotal role of endothelial-specific NFkappaB signaling in the pathogenesis of septic shock and septic vascular dysfunction. J Immunol 2009, 183:4031-4038.

82. Song D, Ye X, Xu H, Liu SF: Activation of endothelial intrinsic NF-\{kappa\}B pathway impairs protein $C$ anticoagulation mechanism and promotes coagulation in endotoxemic mice. Blood 2009, 114:2521-2529. 
83. Grinnell BW, Joyce D: Recombinant human activated protein C: a system modulator of vascular function for treatment of severe sepsis. Crit Care Med 2001, 29:S53-60, discussion S60-51.

84. Brueckmann M, Hoffmann U, De Rossi L, Weiler HM, Liebe V, Lang S, Kaden JJ, Borggrefe M, Haase KK, Huhle G: Activated protein C inhibits the release of macrophage inflammatory protein-1-alpha from THP-1 cells and from human monocytes. Cytokine 2004, 26:106-113.

85. Cheng T, Liu D, Griffin JH, Fernandez JA, Castellino F, Rosen ED, Fukudome K, Zlokovic BV: Activated protein C blocks p53-mediated apoptosis in ischemic human brain endothelium and is neuroprotective. Nat Med 2003, 9:338-342.

86. van Hinsbergh WW, Bertina RM, van Wijngaarden A, van Tilburg NH, Emeis JJ, Haverkate F: Activated protein C decreases plasminogen activator-inhibitor activity in endothelial cell-conditioned medium. Blood 1985, 65:444-451.

87. Sakata Y, Curriden S, Lawrence D, Griffin JH, Loskutoff DJ: Activated protein $\mathrm{C}$ stimulates the fibrinolytic activity of cultured endothelial cells and decreases antiactivator activity. Proc Natl Acad Sci USA 1985, 82:1121-1125.

88. Joyce $D E$, Grinnell BW: Recombinant human activated protein $C$ attenuates the inflammatory response in endothelium and monocytes by modulating nuclear factor-kappaB. Crit Care Med 2002, 30:\$288-293.

89. Brueckmann M, Hoffmann U, Dvortsak E, Lang S, Kaden JJ, Borggrefe M, Haase KK: Drotrecogin alfa (activated) inhibits NF-kappa B activation and MIP-1-alpha release from isolated mononuclear cells of patients with severe sepsis. Inflamm Res 2004, 53:528-533.

90. Heitzer T, Just H, Munzel T: Antioxidant vitamin C improves endothelial dysfunction in chronic smokers. Circulation 1996, 94:6-9.

91. Chambers JC, MCGregor A, Jean-Marie J, Obeid OA, Kooner JS: Demonstration of rapid onset vascular endothelial dysfunction after hyperhomocysteinemia: an effect reversible with vitamin $C$ therapy. Circulation 1999, 99:1156-1160.

92. Timimi FK, Ting HH, Haley EA, Roddy MA, Ganz P, Creager MA: Vitamin C improves endothelium-dependent vasodilation in patients with insulindependent diabetes mellitus. J Am Coll Cardiol 1998, 31:552-557.

93. Ting HH, Timimi FK, Boles KS, Creager SJ, Ganz P, Creager MA: Vitamin C improves endothelium-dependent vasodilation in patients with noninsulin-dependent diabetes mellitus. J Clin Invest 1996, 97:22-28.

94. Solzbach U, Hornig B, Jeserich M, Just H: Vitamin C improves endothelial dysfunction of epicardial coronary arteries in hypertensive patients. Circulation 1997, 96:1513-1519.

95. Gao Y: The multiple actions of NO. Pflugers Arch 459:459-829.

96. Jackson WF: The endothelium-derived relaxing factor. $J$ Reconstr Microsurg 1989, 5:263-271.

97. De Cruz SJ, Kenyon NJ, Sandrock CE: Bench-to-bedside review: the role of nitric oxide in sepsis. Expert Rev Respir Med 2009, 3:511-521.

98. Tyml K, Li F, Wilson JX: Septic impairment of capillary blood flow requires nicotinamide adenine dinucleotide phosphate oxidase but not nitric oxide synthase and is rapidly reversed by ascorbate through an endothelial nitric oxide synthase-dependent mechanism. Crit Care Med 2008, 36:2355-2362.

99. Naseem KM: The role of nitric oxide in cardiovascular diseases. Mol Aspects Med 2005, 26:33-65.

100. Parratt JR: Nitric oxide in sepsis and endotoxaemia. J Antimicrob Chemother 1998, 41(Suppl A):31-39.

101. Wu F, Tyml K, Wilson JX: Ascorbate inhibits iNOS expression in endotoxin- and IFN gamma-stimulated rat skeletal muscle endothelial cells. FEBS Lett 2002, 520:122-126.

102. Wu F, Wilson JX, Tyml K: Ascorbate inhibits iNOS expression and preserves vasoconstrictor responsiveness in skeletal muscle of septic mice. Am J Physiol Regul Integr Comp Physiol 2003, 285:R50-56.

103. Ulker S, McKeown PP, Bayraktutan U: Vitamins reverse endothelial dysfunction through regulation of eNOS and $\mathrm{NAD}(\mathrm{P}) \mathrm{H}$ oxidase activities. Hypertension 2003, 41:534-539.

104. Peluffo G, Calcerrada P, Piacenza L, Pizzano N, Radi R: Superoxide-mediated inactivation of nitric oxide and peroxynitrite formation by tobacco smoke in vascular endothelium: studies in cultured cells and smokers. Am J Physiol Heart Circ Physiol 2009, 296:H1781-1792

105. May JM, Qu ZC, Li X: Ascorbic acid blunts oxidant stress due to menadione in endothelial cells. Arch Biochem Biophys 2003, 411:136-144.
106. Heller R, Munscher-Paulig F, Grabner R, Till U: L-Ascorbic acid potentiates nitric oxide synthesis in endothelial cells. J Biol Chem 1999, 274:8254-8260.

107. Nakai K, Urushihara M, Kubota Y, Kosaka H: Ascorbate enhances iNOS activity by increasing tetrahydrobiopterin in RAW 264.7 cells. Free Radic Biol Med 2003, 35:929-937.

108. d'Uscio LV, Milstien S, Richardson D, Smith L, Katusic ZS: Long-term vitamin $C$ treatment increases vascular tetrahydrobiopterin levels and nitric oxide synthase activity. Circ Res 2003, 92:88-95.

109. Toth M, Kukor Z, Valent S: Chemical stabilization of tetrahydrobiopterin by L-ascorbic acid: contribution to placental endothelial nitric oxide synthase activity. Mol Hum Reprod 2002, 8:271-280.

110. Patel KB, Stratford MR, Wardman P, Everett SA: Oxidation of tetrahydrobiopterin by biological radicals and scavenging of the trihydrobiopterin radical by ascorbate. Free Radic Biol Med 2002, 32:203-211.

111. Stone KJ, Townsley BH: The effect of L-ascorbate on catecholamine biosynthesis. Biochem J 1973, 131:611-613.

112. Huang A, Vita JA, Venema RC, Keaney JF Jr: Ascorbic acid enhances endothelial nitric-oxide synthase activity by increasing intracellular tetrahydrobiopterin. J Biol Chem 2000, 275:17399-17406.

113. Schmidt TS, Alp NJ: Mechanisms for the role of tetrahydrobiopterin in endothelial function and vascular disease. Clin Sci (Lond) 2007, 113:47-63.

114. Keel M, Trentz O: Pathophysiology of polytrauma. Injury 2005, 36:691-709.

115. Rossig L, Hoffmann J, Hugel B, Mallat Z, Haase A, Freyssinet JM, Tedgui A, Aicher A, Zeiher AM, Dimmeler S: Vitamin C inhibits endothelial cell apoptosis in congestive heart failure. Circulation 2001, 104:2182-2187.

116. Haendeler J, Zeiher AM, Dimmeler S: Vitamin C and E prevent lipopolysaccharide-induced apoptosis in human endothelial cells by modulation of Bcl-2 and Bax. Eur J Pharmacol 1996, 317:407-411.

117. Saeed RW, Peng T, Metz CN: Ascorbic acid blocks the growth inhibitory effect of tumor necrosis factor-alpha on endothelial cells. Exp Biol Med (Maywood) 2003, 228:855-865.

118. Fiorito C, Rienzo M, Crimi E, Rossiello R, Balestrieri ML, Casamassimi A, Muto F, Grimaldi V, Giovane A, Farzati B, et al: Antioxidants increase number of progenitor endothelial cells through multiple gene expression pathways. Free Radic Res 2008, 42:754-762.

119. Mo SJ, Son EW, Rhee DK, Pyo S: Modulation of TNF-alpha-induced ICAM-1 expression, $\mathrm{NO}$ and $\mathrm{H} 2 \mathrm{O} 2$ production by alginate, allicin and ascorbic acid in human endothelial cells. Arch Pharm Res 2003, 26:244-251.

120. Martin WJ: Neutrophils kill pulmonary endothelial cells by a hydrogenperoxide-dependent pathway. An in vitro model of neutrophil-mediated lung injury. Am Rev Respir Dis 1984, 130:209-213.

121. Chen YH, Lin SJ, Chen YL, Liu PL, Chen JW: Anti-inflammatory effects of different drugs/agents with antioxidant property on endothelial expression of adhesion molecules. Cardiovasc Hematol Disord Drug Targets 2006, 6:279-304.

122. May JM, Qu ZC: Ascorbic acid prevents increased endothelial permeability caused by oxidized low density lipoprotein. Free Radic Res 44:44-1359.

123. Wilson JX: Mechanism of action of vitamin C in sepsis: ascorbate modulates redox signaling in endothelium. Biofactors 2009, 35:5-13.

124. Utoguchi N, Ikeda K, Saeki K, Oka N, Mizuguchi H, Kubo K, Nakagawa S, Mayumi T: Ascorbic acid stimulates barrier function of cultured endothelial cell monolayer. J Cell Physiol 1995, 163:393-399.

125. Bowie A, O'Neill LA: Vitamin C inhibits NF kappa B activation in endothelial cells. Biochem Soc Trans 1997, 25:131S.

126. Carcamo JM, Pedraza A, Borquez-Ojeda O, Golde DW: Vitamin C suppresses TNF alpha-induced NF kappa B activation by inhibiting I kappa B alpha phosphorylation. Biochemistry 2002, 41:12995-13002.

127. Bowie $A G, O^{\prime}$ Neill LA: Vitamin $C$ inhibits NF-kappa $B$ activation by TNF via the activation of p38 mitogen-activated protein kinase. J Immunol 2000, 165:7180-7188.

128. Rodriguez-Porcel M, Lerman LO, Holmes DR, Richardson D, Napoli C, Lerman A: Chronic antioxidant supplementation attenuates nuclear factor-kappa B activation and preserves endothelial function in hypercholesterolemic pigs. Cardiovasc Res 2002, 53:1010-1018.

129. Chade AR, Rodriguez-Porcel M, Herrmann J, Zhu X, Grande JP, Napoli C, Lerman A, Lerman LO: Antioxidant intervention blunts renal injury in experimental renovascular disease. J Am Soc Nephrol 2004, 15:958-966. 
130. Levine M, Conry-Cantilena C, Wang Y, Welch RW, Washko PW, Dhariwal KR, Park JB, Lazarev A, Graumlich JF, King J, Cantilena LR: Vitamin $C$ pharmacokinetics in healthy volunteers: evidence for a recommended dietary allowance. Proc Natl Acad Sci USA 1996, 93:3704-3709.

131. Hathcock JN, Azzi A, Blumberg J, Bray T, Dickinson A, Frei B, Jialal I, Johnston CS, Kelly FJ, Kraemer K, et al: Vitamins E and C are safe across a broad range of intakes. Am J Clin Nutr 2005, 81:736-745.

132. Eskurza I, Monahan KD, Robinson JA, Seals DR: Effect of acute and chronic ascorbic acid on flow-mediated dilatation with sedentary and physically active human ageing. J Physiol 2004, 556:315-324.

133. McGregor GP, Biesalski HK: Rationale and impact of vitamin C in clinical nutrition. Curr Opin Clin Nutr Metab Care 2006, 9:697-703.

134. Schorah CJ, Downing C, Piripitsi A, Gallivan L, Al-Hazaa AH, Sanderson MJ, Bodenham A: Total vitamin C, ascorbic acid, and dehydroascorbic acid concentrations in plasma of critically ill patients. Am J Clin Nutr 1996, 63:760-765.

135. Sinclair AJ, Taylor PB, Lunec J, Girling AJ, Barnett AH: Low plasma ascorbate levels in patients with type 2 diabetes mellitus consuming adequate dietary vitamin C. Diabet Med 1994, 11:893-898.

136. Du WD, Yuan ZR, Sun J, Tang JX, Cheng AQ, Shen DM, Huang CJ, Song XH, Yu XF, Zheng SB: Therapeutic efficacy of high-dose vitamin $C$ on acute pancreatitis and its potential mechanisms. World J Gastroenterol 2003, 9:2565-2569

137. Bakaev W, Duntau AP: Ascorbic acid in blood serum of patients with pulmonary tuberculosis and pneumonia. Int J Tuberc Lung Dis 2004, 8:263-266

138. Maggio D, Barabani M, Pierandrei M, Polidori MC, Catani M, Mecocci P, Senin U, Pacifici $R$, Cherubini A: Marked decrease in plasma antioxidants in aged osteoporotic women: results of a cross-sectional study. J Clin Endocrinol Metab 2003, 88:1523-1527.

139. Lunec J, Blake DR: The determination of dehydroascorbic acid and ascorbic acid in the serum and synovial fluid of patients with rheumatoid arthritis (RA). Free Radic Res Commun 1985, 1:31-39.

140. Fain O, Mathieu E, Thomas M: Scurvy in patients with cancer. BMJ 1998, 316:1661-1662

141. Mayland CR, Bennett MI, Allan K: Vitamin C deficiency in cancer patients. Palliat Med 2005, 19:17-20.

142. Bodansky O, Wroblewski F, Markardt B: Concentrations of ascorbic acid in plasma and white blood cells of patients with cancer and noncancerous chronic disease. Cancer 1952, 5:678-684.

143. Butcher RG, Chayen J: Oxidation of L-ascorbic acid by cells of carcinoma of the human cervix. Nature 1965, 207:992-993.

144. Fraenkel-Conrat J, Stoy T, Tsai SF: Investigation of ascorbic acid levels in blood of cancer patients compared to normal subjects. Mo Med 1967, 64:1001-1002.

145. Anthony HM, Schorah CJ: Severe hypovitaminosis C in lung-cancer patients: the utilization of vitamin $C$ in surgical repair and lymphocyterelated host resistance. $\mathrm{Br} J$ Cancer 1982, 46:354-367.

146. Gupta A, Bhatt ML, Misra MK: Lipid peroxidation and antioxidant status in head and neck squamous cell carcinoma patients. Oxid Med Cell Longev 2009, 2:68-72

147. Long CL, Maull Kl, Krishnan RS, Laws HL, Geiger JW, Borghesi L, Franks W, Lawson TC, Sauberlich HE: Ascorbic acid dynamics in the seriously ill and injured. J Surg Res 2003, 109:144-148.

148. Kuiper C, Molenaar IG, Dachs GU, Currie MJ, Sykes PH, Vissers MC: Low ascorbate levels are associated with increased hypoxia-inducible factor-1 activity and an aggressive tumor phenotype in endometrial cancer. Cancer Res 70:70-5749.

149. Ghezzi F, Cromi A, Siesto G, Giudici S, Serati M, Formenti G, Franchi M: Prognostic significance of preoperative plasma fibrinogen in endometrial cancer. Gynecol Oncol 119:119-309.

150. Tang L, Liu K, Wang J, Wang C, Zhao P, Liu J: High preoperative plasma fibrinogen levels are associated with distant metastases and impaired prognosis after curative resection in patients with colorectal cancer. $J$ Surg Oncol 102:102-428.

151. Polterauer S, Grimm C, Seebacher V, Concin N, Marth C, Tomovski C, Husslein H, Leipold H, Hefler-Frischmuth K, Tempfer C, et al: Plasma fibrinogen levels and prognosis in patients with ovarian cancer: $a$ multicenter study. Oncologist 2009, 14:979-985.
152. Zhu WL, Fan BL, Liu DL, Zhu WX: Abnormal expression of fibrinogen gamma (FGG) and plasma level of fibrinogen in patients with hepatocellular carcinoma. Anticancer Res 2009, 29:2531-2534.

153. Polterauer S, Seebacher V, Hefler-Frischmuth K, Grimm C, Heinze G, Tempfer $C$, Reinthaller A, Hefler L: Fibrinogen plasma levels are an independent prognostic parameter in patients with cervical cancer. Am J Obstet Gynecol 2009, 200:e641-647.

154. Guo Q, Zhang B, Dong X, Xie Q, Guo E, Huang H, Wu Y: Elevated levels of plasma fibrinogen in patients with pancreatic cancer: possible role of a distant metastasis predictor. Pancreas 2009, 38:e75-79.

155. Takeuchi H, Ikeuchi S, Kitagawa Y, Shimada A, Oishi T, Isobe Y, Kubochi K, Kitajima M, Matsumoto S: Pretreatment plasma fibrinogen level correlates with tumor progression and metastasis in patients with squamous cell carcinoma of the esophagus. J Gastroenterol Hepatol 2007, 22:2222-2227.

156. Lukaszewicz-Zajac M, Mroczko B, Gryko M, Kedra B, Szmitkowski M: Comparison between clinical significance of serum proinflammatory proteins (IL-6 and CRP) and classic tumor markers (CEA and CA 19-9) in gastric cancer. Clin Exp Med 2010

157. Kanz R, Vukovich T, Vormittag R, Dunkler D, Ay C, Thaler J, Haselbock J, Scheithauer W, Zielinski C, Pabinger I: Thrombosis risk and survival in cancer patients with elevated C-reactive protein. J Thromb Haemost 2011, 9(1):57-63.

158. Kocsis J, Meszaros T, Madaras B, Toth EK, Kamondi S, Gal P, Varga L, Prohaszka Z, Fust G: High levels of acute phase proteins and soluble 70 $\mathrm{kDa}$ heat shock proteins are independent and additive risk factors for mortality in colorectal cancer. Cell Stress Chaperones 2011, 16(1):49-55, Epub 2010 Aug 22

159. Prins RC, Rademacher BL, Mongoue-Tchokote S, Alumkal JJ, Graff JN, Eilers KM, Beer TM: C-reactive protein as an adverse prognostic marker for men with castration-resistant prostate cancer (CRPC): Confirmatory results. Urol Oncol 2010.

160. Wang CS, Sun CF: C-reactive protein and malignancy: clinico-pathological association and therapeutic implication. Chang Gung Med J 2009, 32:471-482.

161. Schroecksnadel K, Frick B, Fiegl M, Winkler C, Denz HA, Fuchs D: Hyperhomocysteinaemia and immune activation in patients with cancer. Clin Chem Lab Med 2007, 45:47-53.

162. Miyata $Y$, Koga S, Nishikido M, Noguchi M, Kanda S, Hayashi T, Saito Y, Kanetake $\mathrm{H}$ : Predictive values of acute phase reactants, basic fetoprotein, and immunosuppressive acidic protein for staging and survival in renal cell carcinoma. Urology 2001, 58:161-164.

163. Song MK, Chung JS, Seol YM, Shin HJ, Choi YJ, Cho GJ: Elevation of serum ferritin is associated with the outcome of patients with newly diagnosed multiple myeloma. Korean J Intern Med 2009, 24:368-373.

164. Singh KJ, Singh SK, Suri A, Vijjan V, Goswami AK, Khullar M: Serum ferritin in renal cell carcinoma: effect of tumor size, volume grade, and stage. Indian J Cancer 2005, 42:197-200.

165. Garaventa A, Boni L, Lo Piccolo MS, Tonini GP, Gambini C, Mancini A, Tonegatti L, Carli M, di Montezemolo LC, Di Cataldo A, et al: Localized unresectable neuroblastoma: results of treatment based on clinical prognostic factors. Ann Oncol 2002, 13:956-964

166. Sucher R, Schroecksnadel K, Weiss G, Margreiter R, Fuchs D, Brandacher G Neopterin, a prognostic marker in human malignancies. Cancer Lett 287:287-13.

167. Melichar B, Solichova D, Freedman RS: Neopterin as an indicator of immune activation and prognosis in patients with gynecological malignancies. Int J Gynecol Cancer 2006, 16:240-252.

168. Murr C, Fuith LC, Widner B, Wirleitner B, Baier-Bitterlich G, Fuchs D: Increased neopterin concentrations in patients with cancer: indicator of oxidative stress? Anticancer Res 1999, 19:1721-1728.

169. Ferroni P, Palmirotta R, Martini F, Riondino S, Savonarola A, Spila A, Ciatti F, Sini V, Mariotti S, Del Monte G, et al: Determinants of homocysteine levels in colorectal and breast cancer patients. Anticancer Res 2009, 29:4131-4138.

170. Almadori G, Bussu F, Galli J, Cadoni G, Zappacosta B, Persichilli S, Minucci A Giardina B, Maurizi M: Serum levels of folate, homocysteine, and vitamin B12 in head and neck squamous cell carcinoma and in laryngeal leukoplakia. Cancer 2005, 103:284-292.

171. Blay JY, Negrier S, Combaret V, Attali S, Goillot E, Merrouche Y, Mercatello A, Ravault A, Tourani JM, Moskovtchenko JF, et al: Serum level of interleukin 
6 as a prognosis factor in metastatic renal cell carcinoma. Cancer Res 1992, 52:3317-3322.

172. Salzman R, Pacal L, Tomandl J, Kankova K, Tothova E, Gal B, Kostrica R, Salzman P: Elevated malondialdehyde correlates with the extent of primary tumor and predicts poor prognosis of oropharyngeal cancer. Anticancer Res 2009, 29:4227-4231.

173. Arsova-Sarafinovska Z, Eken A, Matevska N, Erdem O, Sayal A, Savaser A, Banev S, Petrovski D, Dzikova S, Georgiev V, et al: Increased oxidative/ nitrosative stress and decreased antioxidant enzyme activities in prostate cancer. Clin Biochem 2009, 42:1228-1235.

174. Patel BP, Rawal UM, Dave TK, Rawal RM, Shukla SN, Shah PM, Patel PS: Lipid peroxidation, total antioxidant status, and total thiol levels predict overall survival in patients with oral squamous cell carcinoma. Integr Cancer Ther 2007, 6:365-372.

175. Ray G, Batra S, Shukla NK, Deo S, Raina V, Ashok S, Husain SA: Lipid peroxidation, free radical production and antioxidant status in breast cancer. Breast Cancer Res Treat 2000, 59:163-170.

176. Fain O, Paries J, Jacquart B, Le Moel G, Kettaneh A, Stirnemann J, Heron C, Sitbon M, Taleb C, Letellier E, et al: Hypovitaminosis C in hospitalized patients. Eur J Intern Med 2003, 14:419-425.

177. Kubota Y, Moriyama Y, Yamagishi K, Tanigawa T, Noda H, Yokota K, Harada M, Inagawa M, Oshima M, Sato S, Iso H: Serum vitamin C concentration and hs-CRP level in middle-aged Japanese men and women. Atherosclerosis 208:208-496.

178. Block G, Jensen CD, Dalvi TB, Norkus EP, Hudes M, Crawford PB, Holland N, Fung EB, Schumacher L, Harmatz P: Vitamin C treatment reduces elevated C-reactive protein. Free Radic Biol Med 2009, 46:70-77.

179. Mayland C, Allen KR, Degg TJ, Bennet M: Micronutrient concentrations in patients with malignant disease: effect of the inflammatory response. Ann Clin Biochem 2004, 41:138-141.

180. Kaehler J, Koeke K, Karstens M, Schneppenheim R, Meinertz T, Heitzer T: Impaired capacity for acute endogenous fibrinolysis in smokers is restored by ascorbic acid. Free Radic Biol Med 2008, 44:315-321.

181. Korantzopoulos P, Kolettis TM, Kountouris E, Dimitroula V, Karanikis $P$, Pappa E, Siogas K, Goudevenos JA: Oral vitamin C administration reduces early recurrence rates after electrical cardioversion of persistent atrial fibrillation and attenuates associated inflammation. Int J Cardiol 2005, 102:321-326

182. Bohm F, Settergren M, Pernow J: Vitamin C blocks vascular dysfunction and release of interleukin- 6 induced by endothelin-1 in humans in vivo. Atherosclerosis 2007, 190:408-415.

183. Murr C, Winklhofer-Roob BM, Schroecksnadel K, Maritschnegg M, Mangge H, Bohm BO, Winkelmann BR, Marz W, Fuchs D: Inverse association between serum concentrations of neopterin and antioxidants in patients with and without angiographic coronary artery disease. Atherosclerosis 2009, 202:543-549.

184. Doise JM, Aho LS, Quenot JP, Guilland JC, Zeller M, Vergely C, Aube H, Blettery B, Rochette L: Plasma antioxidant status in septic critically ill patients: a decrease over time. Fundam Clin Pharmacol 2008, 22:203-209.

185. Borrelli E, Roux-Lombard P, Grau GE, Girardin E, Ricou B, Dayer J, Suter PM: Plasma concentrations of cytokines, their soluble receptors, and antioxidant vitamins can predict the development of multiple organ failure in patients at risk. Crit Care Med 1996, 24:392-397.

186. Galley HF, Davies MJ, Webster NR: Ascorbyl radical formation in patients with sepsis: effect of ascorbate loading. Free Radic Biol Med 1996, 20:139-143.

187. Gaut JP, Belaaouaj A, Byun J, Roberts LJ, Maeda N, Frei B, Heinecke JW: Vitamin $C$ fails to protect amino acids and lipids from oxidation during acute inflammation. Free Radic Biol Med 2006, 40:1494-1501.

188. Shen KP, Lo YC, Yang RC, Liu HW, Chen IJ, Wu BN: Antioxidant eugenosedin-A protects against lipopolysaccharide-induced hypotension, hyperglycaemia and cytokine immunoreactivity in rats and mice. J Pharm Pharmacol 2005, 57:117-125.

189. Tyml K, Li F, Wilson JX: Delayed ascorbate bolus protects against maldistribution of microvascular blood flow in septic rat skeletal muscle. Crit Care Med 2005, 33:1823-1828.

190. Wu F, Wilson JX, Tyml K: Ascorbate protects against impaired arteriolar constriction in sepsis by inhibiting inducible nitric oxide synthase expression. Free Radic Biol Med 2004, 37:1282-1289.

191. Crimi E, Liguori A, Condorelli M, Cioffi M, Astuto M, Bontempo P, Pignalosa O, Vietri MT, Molinari AM, Sica V, et al: The beneficial effects of antioxidant supplementation in enteral feeding in critically ill patients: a prospective, randomized, double-blind, placebo-controlled trial. Anesth Analg 2004, 99:857-863, table of contents.

192. Nathens AB, Neff MJ, Jurkovich GJ, Klotz P, Farver K, Ruzinski JT, Radella F, Garcia I, Maier RV: Randomized, prospective trial of antioxidant supplementation in critically ill surgical patients. Ann Surg 2002, 236:814-822.

193. Tanaka H, Matsuda T, Miyagantani Y, Yukioka T, Matsuda H, Shimazaki S: Reduction of resuscitation fluid volumes in severely burned patients using ascorbic acid administration: a randomized, prospective study. Arch Surg 2000, 135:326-331.

194. Deubzer B, Mayer F, Kuci Z, Niewisch M, Merkel G, Handgretinger R, Bruchelt G: $\mathrm{H}(2) \mathrm{O}(2)$-mediated cytotoxicity of pharmacologic ascorbate concentrations to neuroblastoma cells: potential role of lactate and ferritin. Cell Physiol Biochem 25:25-767.

195. Gilloteaux J, Jamison JM, Neal DR, Loukas M, Doberzstyn T, Summers JL: Cell damage and death by autoschizis in human bladder (RT4) carcinoma cells resulting from treatment with ascorbate and menadione. Ultrastruct Pathol 34:34-140.

196. Cullen JJ: Ascorbate induces autophagy in pancreatic cancer. Autophagy 6:6-421.

197. Takemura Y, Satoh M, Satoh K, Hamada H, Sekido Y, Kubota S: High dose of ascorbic acid induces cell death in mesothelioma cells. Biochem Biophys Res Commun 394:394-249.

198. Verrax J, Pedrosa RC, Beck R, Dejeans N, Taper H, Calderon PB: In situ modulation of oxidative stress: a novel and efficient strategy to kill cancer cells. Curr Med Chem 2009, 16:1821-1830.

199. Fromberg A, Gutsch D, Schulze D, Vollbracht C, Weiss G, Czubayko F, Aigner A: Ascorbate exerts anti-proliferative effects through cell cycle inhibition and sensitizes tumor cells towards cytostatic drugs. Cancer Chemother Pharmacol 2010.

200. Pollard HB, Levine MA, Eidelman O, Pollard M: Pharmacological ascorbic acid suppresses syngeneic tumor growth and metastases in hormonerefractory prostate cancer. In Vivo 24:24-249.

201. Padayatty SJ, Riordan HD, Hewitt SM, Katz A, Hoffer LJ, Levine M: Intravenously administered vitamin C as cancer therapy: three cases. CMAJ 2006, 174:937-942.

202. Mikirova NA, Ichim TE, Riordan NH: Anti-angiogenic effect of high doses of ascorbic acid. J Transl Med 2008, 6:50.

203. Ashino H, Shimamura M, Nakajima H, Dombou M, Kawanaka S, Oikawa T, Iwaguchi T, Kawashima S: Novel function of ascorbic acid as an angiostatic factor. Angiogenesis 2003, 6:259-269.

204. Mikirova NA, Casciari JJ, Riordan NH: Ascorbate inhibition of angiogenesis in aortic rings ex vivo and subcutaneous Matrigel plugs in vivo. $J$ Angiogenes Res 2:2.

205. Yeom CH, Lee G, Park JH, Yu J, Park S, Yi SY, Lee HR, Hong YS, Yang J, Lee $S$ : High dose concentration administration of ascorbic acid inhibits tumor growth in BALB/C mice implanted with sarcoma 180 cancer cells via the restriction of angiogenesis. J Transl Med 2009, 7:70.

206. Muellner MK, Schreier SM, Schmidbauer B, Moser M, Quehenberger P, Kapiotis S, Goldenberg H, Laggner H: Vitamin C inhibits NO-induced stabilization of HIF-1alpha in HUVECs. Free Radic Res 44:44-783.

207. Horak P, Crawford AR, Vadysirisack DD, Nash ZM, DeYoung MP, Sgroi D, Ellisen LW: Negative feedback control of HIF-1 through REDD1-regulated ROS suppresses tumorigenesis. Proc Natl Acad Sci USA 107:4675-4680.

208. Gao P, Zhang H, Dinavahi R, Li F, Xiang Y, Raman V, Bhujwalla ZM, Felsher DW, Cheng L, Pevsner J, et al: HIF-dependent antitumorigenic effect of antioxidants in vivo. Cancer Cell 2007, 12:230-238.

209. Tatla S, Woodhead V, Foreman JC, Chain BM: The role of reactive oxygen species in triggering proliferation and IL-2 secretion in T cells. Free Radic Biol Med 1999, 26:14-24.

210. Williams MS, Kwon J: T cell receptor stimulation, reactive oxygen species, and cell signaling. Free Radic Biol Med 2004, 37:1144-1151.

211. Schwager J, Schulze J: Influence of ascorbic acid on the response to mitogens and interleukin production of porcine lymphocytes. Int I Vitam Nutr Res 1997, 67:10-16.

212. Eylar E, Baez I, Navas J, Mercado C: Sustained levels of ascorbic acid are toxic and immunosuppressive for human T cells. P R Health Sci J 1996, 15:21-26.

213. Huwyler T, Hirt A, Morell A: Effect of ascorbic acid on human natural killer cells. Immunol Lett 1985, 10:173-176. 
214. Tan PH, Sagoo P, Chan C, Yates JB, Campbell J, Beutelspacher SC, Foxwell BM, Lombardi G, George AJ: Inhibition of NF-kappa B and oxidative pathways in human dendritic cells by antioxidative vitamins generates regulatory T cells. J Immunol 2005, 174:7633-7644.

215. Chen S, Yang L, Li Y: TCR zeta chain expression in T cells from patients with CML. Hematology 2009, 14:95-100.

216. Kulkarni DP, Wadia PP, Pradhan TN, Pathak AK, Chiplunkar SV: Mechanisms involved in the down-regulation of TCR zeta chain in tumor versus peripheral blood of oral cancer patients. Int J Cancer 2009, 124:1605-1613.

217. Gruber IV, El Yousfi S, Durr-Storzer S, Wallwiener D, Solomayer EF, Fehm T: Down-regulation of CD28, TCR-zeta (zeta) and up-regulation of FAS in peripheral cytotoxic T-cells of primary breast cancer patients. Anticancer Res 2008, 28:779-784

218. Pignataro L, Pagani D, Brando B, Sambataro G, Scarpati B, Corsi MM: Downregulation of zeta chain and zeta-associated protein 70 (Zap 70) expression in circulating $\mathrm{T}$ lymphocytes in laryngeal squamous cell carcinoma. Anal Quant Cytol Histol 2007, 29:57-62.

219. Zehbe I, Schmidt M, Maeurer M, Leo C, Hockel M, Pilch H: Different T-cell receptor (TCR) zeta chain expression in cervical cancer and its precursor lesions. Zentralb/ Gynakol 2006, 128:266-270.

220. Ciszak L, Pawlak E, Kosmaczewska A, Potoczek S, Frydecka I: Alterations in the expression of signal-transducing CD3 zeta chain in T cells from patients with chronic inflammatory/autoimmune diseases. Arch Immunol Ther Exp (Warsz) 2007, 55:373-386.

221. Baniyash M: TCR zeta-chain downregulation: curtailing an excessive inflammatory immune response. Nat Rev Immunol 2004, 4:675-687.

222. Pitcher LA, van Oers NS: T-cell receptor signal transmission: who gives an ITAM? Trends Immunol 2003, 24:554-560.

223. Gastman BR, Johnson DE, Whiteside TL, Rabinowich H: Tumor-induced apoptosis of T lymphocytes: elucidation of intracellular apoptotic events. Blood 2000, 95:2015-2023.

224. Boussiotis VA, Barber DL, Lee BJ, Gribben JG, Freeman GJ, Nadler LM: Differential association of protein tyrosine kinases with the $T$ cell receptor is linked to the induction of anergy and its prevention by B7 family-mediated costimulation. J Exp Med 1996, 184:365-376.

225. Kim CW, Choi SH, Chung EJ, Lee MJ, Byun EK, Ryu MH, Bang YJ: Alteration of signal-transducing molecules and phenotypical characteristics in peripheral blood lymphocytes from gastric carcinoma patients. Pathobiology 1999, 67:123-128.

226. Reichert TE, Day R, Wagner EM, Whiteside TL: Absent or low expression of the zeta chain in T cells at the tumor site correlates with poor survival in patients with oral carcinoma. Cancer Res 1998, 58:5344-5347.

227. Zea AH, Curti BD, Longo DL, Alvord WG, Strobl SL, Mizoguchi H, Creekmore SP, O'Shea JJ, Powers GC, Urba WJ, et al: Alterations in T cell receptor and signal transduction molecules in melanoma patients. Clin Cancer Res 1995, 1:1327-1335.

228. Healy CG, Simons JW, Carducci MA, DeWeese TL, Bartkowski M, Tong KP, Bolton WE: Impaired expression and function of signal-transducing zeta chains in peripheral T cells and natural killer cells in patients with prostate cancer. Cytometry 1998, 32:109-119.

229. Mulder WM, Bloemena E, Stukart MJ, Kummer JA, Wagstaff J, Scheper RJ: T cell receptor-zeta and granzyme B expression in mononuclear cell infiltrates in normal colon mucosa and colon carcinoma. Gut 1997, 40:113-119.

230. Muller D, Lang S, Roskrow M, Wollenberg B: [The expression of zeta-chain of the $T$ cell receptor as prognostic marker for patients with head and neck cancer]. Laryngorhinootologie 2002, 81:516-520.

231. Whiteside TL: Down-regulation of zeta-chain expression in T cells: a biomarker of prognosis in cancer? Cancer Immunol Immunother 2004, 53:865-878.

232. Eleftheriadis T, Kartsios C, Yiannaki E, Antoniadi G, Kazila P, Pliakos K, Liakopoulos V, Markala D: Decreased CD3+CD16+ natural killer-like T-cell percentage and zeta-chain expression accompany chronic inflammation in haemodialysis patients. Nephrology (Carlton) 2009, 14:471-475.

233. Eleftheriadis T, Kartsios C, Yiannaki E, Kazila P, Antoniadi G, Liakopoulos V Markala D: Chronic inflammation and CD16+ natural killer cell zeta-chain downregulation in hemodialysis patients. Blood Purif 2008, 26:317-321.

234. Nambiar MP, Krishnan S, Warke VG, Tsokos GC: TCR zeta-chain abnormalities in human systemic lupus erythematosus. Methods Mol Med 2004, 102:49-72.
235. Takeuchi T, Tsuzaka K, Abe T, Yoshimoto K, Shiraishi K, Kameda H, Amano K: T cell abnormalities in systemic lupus erythematosus. Autoimmunity 2005, 38:339-346.

236. Berg L, Ronnelid J, Klareskog L, Bucht A: Down-regulation of the T cell receptor CD3 zeta chain in rheumatoid arthritis (RA) and its influence on T cell responsiveness. Clin Exp Immunol 2000, 120:174-182.

237. Maurice MM, Lankester AC, Bezemer AC, Geertsma MF, Tak PP, Breedveld FC, van Lier RA, Verweij CL: Defective TCR-mediated signaling in synovial T cells in rheumatoid arthritis. J Immunol 1997, 159:2973-2978.

238. Ammirati E, Vermi AC, Cianflone D, Banfi M, Foglieni C, Godino C, Airoldi F, Ferri LA, Gorman CL, Manfredi AA, et al: Expansion of T-cell receptor zeta dim effector T cells in acute coronary syndromes. Arterioscler Thromb Vasc Biol 2008, 28:2305-2311.

239. Sikora J, Dworacki G, Giersz R, Zeromski J: The role of monocytes/ macrophages in TCR-zeta chain downregulation and apoptosis of $T$ lymphocytes in malignant pleural effusions. J Biol Regul Homeost Agents 2004, 18:26-32

240. Markiewski MM, DeAngelis RA, Benencia F, Ricklin-Lichtsteiner SK, Koutoulaki A, Gerard C, Coukos G, Lambris JD: Modulation of the antitumor immune response by complement. Nat Immunol 2008, 9:1225-1235

241. Corzo CA, Cotter MJ, Cheng P, Cheng F, Kusmartsev S, Sotomayor E, Padhya T, McCaffrey TV, McCaffrey JC, Gabrilovich DI: Mechanism regulating reactive oxygen species in tumor-induced myeloid-derived suppressor cells. J Immunol 2009, 182:5693-5701.

242. Choi JY, Oughton JA, Kerkvliet NI: Functional alterations in CD11b(+)Gr-1 $(+)$ cells in mice injected with allogeneic tumor cells and treated with 2,3,7,8-tetrachlorodibenzo-p-dioxin. Int Immunopharmacol 2003, 3:553-570.

243. Makarenkova VP, Bansal V, Matta BM, Perez LA, Ochoa JB: CD11b+/Gr-1+ myeloid suppressor cells cause $T$ cell dysfunction after traumatic stress. J Immunol 2006, 176:2085-2094.

244. Ezernitchi AV, Vaknin I, Cohen-Daniel L, Levy O, Manaster E, Halabi A, Pikarsky E, Shapira L, Baniyash M: TCR zeta down-regulation under chronic inflammation is mediated by myeloid suppressor cells differentially distributed between various lymphatic organs. J Immunol 2006, 177:4763-4772.

245. Schmielau J, Finn OJ: Activated granulocytes and granulocyte-derived hydrogen peroxide are the underlying mechanism of suppression of tcell function in advanced cancer patients. Cancer Res 2001, 61:4756-4760.

246. Nambiar MP, Fisher CU, Enyedy EJ, Warke VG, Kumar A, Tsokos GC: Oxidative stress is involved in the heat stress-induced downregulation of TCR zeta chain expression and TCR/CD3-mediated $[\mathrm{Ca}(2+)](\mathrm{i})$ response in human T-lymphocytes. Cell Immunol 2002, 215:151-161.

\section{doi:10.1186/1479-5876-9-25}

Cite this article as: Ichim et al.: Intravenous ascorbic acid to prevent and treat cancer-associated sepsis? Journal of Translational Medicine 2011 9:25.

\section{Submit your next manuscript to BioMed Central and take full advantage of:}

- Convenient online submission

- Thorough peer review

- No space constraints or color figure charges

- Immediate publication on acceptance

- Inclusion in PubMed, CAS, Scopus and Google Scholar

- Research which is freely available for redistribution

Submit your manuscript at www.biomedcentral.com/submit
C Biomed Central 